\title{
ENOTA ZA SPECIALNO DELOVANJE SLOVENSKE VOJSKE - ODGOVOR NA SODOBNE IZZIVE
}

\section{THE SAF SPECIAL OPERATIONS UNIT RESPONSE TO MODERN CHALLENGES}

Povzetek Enota za specialno delovanje (ESD) zagotavlja zmogljivosti specialnega delovanja Slovenske vojske in uresničevanje posebnih nacionalnovarnostnih ciljev Republike Slovenije.

Visoka usposobljenost, sposobnost prikritega delovanja, zmožnost velike natančnosti zaradi zmanjševanja stranskih učinkov in visoka prilagodljivost glede na različne vire ogrožanja so samo nekatere značilnosti, ki poudarjajo vlogo in pomen ESD znotraj oboroženih sil. Te značilnosti omogočajo njeno uporabo za izpolnjevanje obveznosti Republike Slovenije do sistema kolektivne obrambe zveze Nato ter zagotavljanje mednarodne varnosti znotraj OZN v mednarodnih operacijah in na misijah, ko drugih enot ter virov Slovenske vojske ni mogoče uporabiti. Hkrati je ESD potencialna zmogljivost za obrambo države in delovanje v posebnih kriznih razmerah protiterorističnega delovanja v Republiki Sloveniji.

ESD je s potrditvijo svojih zmogljivosti v praksi pokazala, da so predlagani teoretični koncepti in rešitve, na katerih temelji, pravilni in uresničljivi, ESD pa vrhunsko usposobljena enota, ki predstavlja ost enot za bojno delovanje Slovenske vojske.

Ključne Specialno delovanje, protiterorizem, protiuporništvo, Nato, Enota za specialno besede delovanje, na učinkih temelječe operacije.

Abstract The Special Operations Unit (SOU) provides special operations capabilities for the Slovenian Armed Forces (SAF) and the implementation of special national security objectives for the Republic of Slovenia.

Specialized training, the ability to perform covert operations, high accuracy to achieve collateral damage reduction, and great flexibility in facing different sources of threat are but a few of the features that highlight the role and importance of the Special Forces units of the armed forces. Having such characteristics, the unit can be used to fulfil the obligations of the Republic of Slovenia to NATO's collective defence system and ensure the international security of UN missions when no other 
SAF units and capabilities can be employed. At the same time, the SOU provides potential capabilities for national defence and specific crisis situations for counterterrorism activities in the Republic of Slovenia.

By validating its capabilities in practice, the SOU has shown that the theoretical concepts on which it is based are both good and feasible. It has proved itself to be a highly qualified unit - the elite of the SAF's combat operations units.

Key words Special Forces, special operations, counter-terrorism, counter-insurgency, NATO, Special Operations Unit, effects-based operations.

Uvod Spremenjene grožnje in narava konfliktov v obdobju po hladni vojni ter projekcija prihodnjega varnostnega okolja zahtevajo od držav in organizacij (npr. OZN, EU, Nata in drugih) drugačen in predvsem učinkovitejši način soočanja s temi izzivi ${ }^{1}$. Grožnje in izzivi imajo seveda pomembne implikacije ter zahtevajo tudi pomembne spremembe v varnostnih sistemih in oboroženih silah - vključno s specialnimi silami.

Resolucija o splošnem dolgoročnem programu razvoja in opremljanja Slovenske vojske do leta 2025 - ReSDPRO SV 2025 (2010, str. 7) navaja, /.../ da se je v evroatlantskem prostoru močno zmanjšala verjetnost izbruha oboroženih meddržavnih spopadov. Vojaške grožnje se bodo pojavljale predvsem v obliki lokalnih in regionalnih nestabilnosti, ki lahko hitro prerastejo svoj okvir. Sodobne grožnje prevzemajo vse bolj hibridno obliko, njihov značaj pa zaradi močnih globalizacijskih vplivov postaja večplasten in mednaroden, takšni pa so tudi njihovi učinki. Bojišče prihodnosti bo poleg kopnega, morja in zraka obsegalo tudi kibernetski prostor in vesolje.

Avtorji tako menimo, da bo varnostno okolje prihodnosti postalo še bolj zapleteno zaradi kombinacije različnih elementov: večjih ubojnih zmožnosti sodobnega orožja, razvoja sredstev za hitro premikanje vojaških sil, mednarodnega terorizma ${ }^{2}$, širjenja orožja za množično uničevanje, lažjega dostopa do informacij, prisotnosti medijev ipd. Z vojaškimi strukturami in metodami ${ }^{3}$, ki so ustrezale reševanju meddržavnih konfliktov, ne bo mogoče obvladovati zahtevnih varnostnih razmer 21. stoletja.

\footnotetext{
Prevladujoče stališče med različnimi obrambnimi in varnostnimi subjekti v svetu je, da sedanje in prihodnje varnostno okolje pred nas postavljata zapletene izzive, ki jih je težko predvideti. Zelo raznolike in nekonvencionalne grožnje lahko ogrozijo širšo mednarodno stabilnost in povzročijo trajno konfliktno stanje. Specialne sile so dejaven instrument, ki je idealno prilagojen nejasnemu in dinamičnemu okolju, po drugi strani pa ohranja svobodo delovanja z uporabo načela varčnosti sil. Dodatno imajo specialne sile posebno zmožnost za izvedbo nalog $v$ okoljih, v katerih so konvencionalne sile v primerjavi s specialnimi v strateško ali operativno slabšem položaju (NATO Special Operations Study, 2008).

2 Terorizem je tipičen primer sodobne asimetrične grožnje, pri čemer Prezelj (2007, str. 67) ugotavlja, »/.../da se asimetrija nanaša na neproporcionalnost subjekta, ki ogroža (nedržavni akterji proti državi), sredstev, ki jih uporablja, in posledic (minimalni vložek - maksimalni rezultati, ki na primer presegajo neposredne posledice bombne eksplozije)."

3 Seveda je lahko ESD le segment v celovitem odzivu sodobne države na terorizem (Prezelj, 2007, str. 68) in dopolnjuje skupno dejavnost in odziv države (skupna slika).
} 
Tako Srednjeročni obrambni program 2007-2012 (SOPR) iz leta 2006 nakazuje, da bodo na prihodnje strateško varnostno okolje bistveno vplivali: globalizacija, sofisticirana ubojna sredstva in različne oblike asimetričnega vojskovanja, hitro se spreminjajoče varnostne razmere, demografski in politični dejavniki ter pomanjkanje virov, ki povzročajo množične migracije prebivalstva, razmah radikalnih ideologij, nerešene meddržavne in notranje konflikte ter naravne nesreče večjih razsežnosti. SOPR predvideva tudi, da bodo zaradi globalizacije zahodne demokracije, še posebej njihove ekonomije, vse bolj občutljive na stabilnost v različnih delih sveta, ki bo posredno ali neposredno vplivala na njihov ekonomski interes in delovanje prostega trga.

Informacijska omrežja že danes omogočajo pregled nad dogajanji kjer koli na svetu in v realnem času. To dejstvo bodo $\mathrm{v}$ prihodnje $\mathrm{z}$ informacijskimi strategijami izkoriščali različni akterji, tudi taki, katerih glavni namen je uničevalno delovanje. Zaradi vse bolj preprostega in razširjenega dostopa do sodobnih in naprednih tehnologij bodo teroristični in drugi napadi vse bolj učinkoviti. Vse bolj izrazita bo grožnja možnosti dostopa do tehnologij in sredstev za množično uničevanje, ki jih bodo sponzorirale tudi države (SOPR 2007-2012).

Razkorak med razvitimi in nerazvitimi državami bo še naprej povzročal etnične konflikte ter množične migracije. Gospodarske in finančne krize bodo povzročale pritisk in razkrajale socialne sisteme (SOPR 2007-2012).

Zahteve po energetskih virih, vodi in hrani bodo naraščale, podnebne spremembe pa bodo negativno vplivale na možnosti za zagotavljanje vode in hrane. Zaradi degradacije okolja se bo verjetno povečalo število naravnih nesreč, ki bodo dolgoročno vplivale na socialne in ekonomske razmere v nekaterih delih sveta. Naraščala bosta organizirani kriminal in siromaštvo, pojavljale se bodo nove bolezni in lakota (SOPR 2007-2012).

Izvor ogrožanja bodo nestabilne države, slabo upravljanje virov in nenehno tekmovanje zanje. Nerešeni konflikti ter skupine in države, ki podpirajo radikalne ideologije, bodo predstavljali grožnje, ki lahko dosežejo globalne razsežnosti. Tako lahko nekatere hujše oblike navedenih groženj v temeljih zamajejo globalno stabilnost (Rode, 2007, str. 5).

Strateško presenečenje je mogoče in zanj bo malo ali nič predhodnih opozoril. Zato bo sodelovanje v Natu pomembno, hkrati pa realna možnost, da se sproži institut kolektivne obrambe.

Razmere na Balkanu bodo tudi v prihodnje nestabilne. Problematično ostaja predvsem Kosovo. Kljub temu se bodo mednarodne sile, ki zagotavljajo stabilnost na Kosovu in v BiH, prestrukturirale in zmanjšale. Proces širitve Nata in EU na južne balkanske države pa se bo nadaljeval. 
Varnostne razmere v Afriki bodo tudi v prihodnje kritične, nanje pa bodo vplivali različni dejavniki, kot so hitra demografska rast prebivalstva, epidemije, revščina, lakota, pomanjkanje vode, nestabilni režimi, propadle države, medverska in medetnična trenja itn. Ti dejavniki in razmere, ki jih bodo ustvarjali, bodo povzročali ilegalne migracije $\mathrm{v}$ Evropo ter razraščanje terorističnih skupin, ki bodo svoje delovanje usmerjale tudi v Evropo (SOPR 2007-2012). Zaenkrat pa tako imenovana arabska pomlad v Tuniziji, Egiptu, Libiji in drugje še ni potrdila črnogledih napovedi.

Bližnji vzhod bo ostal krizno žarišče, na katerem se bodo nadaljevali medetnični in medverski spopadi, širjenje različnih oblik fanatizma ter posledično terorističnih delovanj, ki se lahko usmerijo tudi v evropske države (SOPR 2007-2012).

Spekter vojskovanja bo v prihodnosti usmerjen v krize, v katerih je lahko uporabljeno jedrsko in drugo orožje za množično uničevanje, v klasične meddržavne spopade, notranje konflikte, ki povzročajo propad držav, v terorizem in druge krizne razmere. Poseben izziv bo dejstvo, da se v različne dimenzije vojskovanja ne vključujejo zgolj oborožene sile, pač pa različni akterji: državni, mednarodni, nevladni in lokalni ter vsi elementi različnih instrumentov moči, kot so politični, vojaški, informacijski, ekonomski in drugi.

$\mathrm{Na}$ vojaške grožnje država običajno odgovori z oboroženimi silami. Tako bodo v prihodnje tudi enote SV z nadaljevanjem procesa integracije v zavezništvo prevzemale vse večje obveznosti, ne le v smislu velikosti in številčnosti sodelujočih enot, temveč tudi v smislu kompleksnosti in težavnosti dodeljenih nalog.

\section{NATO, SLOVENSKA VOJSKA IN SPECIALNE SILE (SPECIAL OPERATIONS FORCES - SOF)}

Na podlagi spoznanj in izkušenj, predvsem iz operacij specialnih sil v Afganistanu, je bila leta 2006 na vrhunskem zasedanju Nata v Rigi sprejeta odločitev o preoblikovanju specialnih sil zveze (NATO SOF Transformation Initiative) za doseganje večje medsebojne primerljivosti in zmožnosti skupnega delovanja. Ta cilj naj bi bil dosežen predvsem s skupnim usposabljanjem, opremljanjem ter $\mathrm{z}$ uvedbo in doseganjem skupnih standardov. S tem namenom je bil leta 2007 ustanovljen tudi Koordinacijski center za specialne operacije zveze Nato (NATO SOF Coordination Centre - NSCC), ki se je na začetku leta 2010 preoblikoval v Poveljstvo za specialno delovanje zveze Nato (NATO Special Operations Headquarters - NSHQ). Pozneje je postal tudi edino telo za vodenje in usklajevanje specialnih operacij Nata, namenjeno optimizaciji uporabe specialnih sil zavezništva in zagotavljanju zmogljivosti operativnega poveljevanja skladno z usmeritvami SACEUR (glej Beršnak, 2010, str. 27-28).

Kot navaja Paternus (2010, str. 70) je Severnoatlantski svet leta 2006 kot izhodišče za uvedbo skupnih standardov sprejel dokument MC 437/1 Special Operations Policy, ki predstavlja temelj za oblikovanje skupne Natove doktrine za specialne operacije. Leta 2008 je bil začet proces ratifikacije AJP 3.5, Allied Joint Doctrine for Special 
Operations, ki je bil končan leta 2009, ko je bil dokument tudi ratificiran kot SVS STANAG 2523(1).

Dva najpomembnejša dokumenta o področju specialnih sil sta prav MC 437/1 Special Operations Policy in AJP 3.5, ki opredeljujeta pomen in namen specialnih sil v nacionalni in kolektivni obrambi, organizacijske modele, finančni vidik, minimalne zahtevane zmogljivosti itn.

Vojaška doktrina Slovenske vojske definira specialne sile kot eno izmed komponent skupnih združenih namenskih sil (Combined Joint Task Force - CJTF) (slika 1), ki se organizirajo glede na svoje poslanstvo, združeno območje delovanja ter prevladujoči način delovanja. Skupne združene namenske sile poleg specialnih sil vključujejo še zračno, mornariško in kopensko komponento (glej Furlan idr., 2006, str. 29).

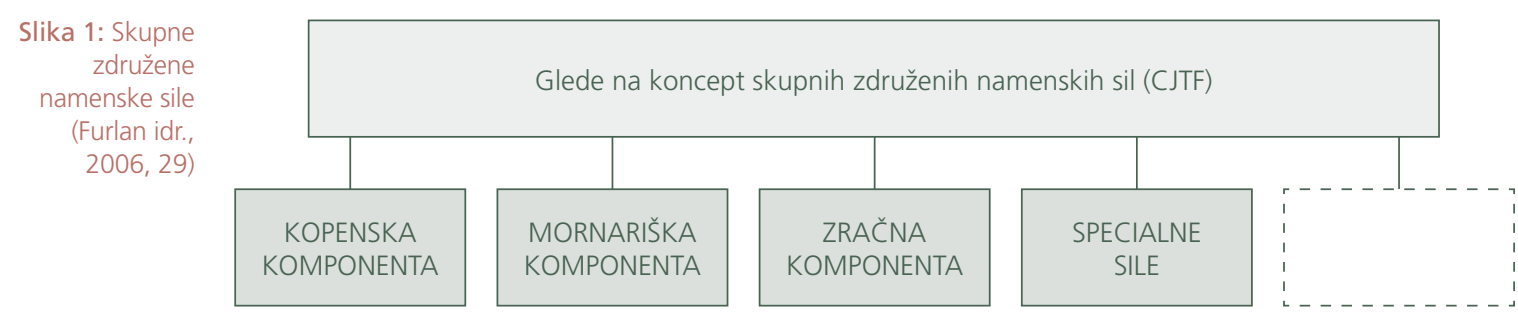

Specialne sile SV so nosilec specialnega delovanja, ki /... / je način bojnega delovanja posebej izbranih, opremljenih, organiziranih in usposobljenih enot Slovenske vojske. Te ga izvajajo z namenom podpore doseganju vojaških, političnih ali psiholoških ciljev, ki imajo operativni ali strateški pomen. Specialno delovanje obsega nekonvencionalne vrste bojnega delovanja, direktne akcije, specialno izvidovanje, obveščevalno dejavnost, protiteroristično delovanje, psihološko delovanje ter bojno iskanje in reševanje. Vse aktivnosti specialnih sil so usmerjene v vojaške cilje. (Furlan idr., 2006, str. 50)

Furlan (idr. 2006, str. 50) je opredelil, da so značilnosti uporabe specialnih enot Slovenske vojske /.../ delovanje v manjših skupinah, samostojno, na večjih globinah in $v$ daljšem časovnem obdobju ter prikritost delovanja. Svoje naloge izvajajo pri ofenzivnem, defenzivnem, informacijskem in stabilizacijskem delovanju Slovenske vojske. Vokoliščinah, ko sovražnik zasede in nadzira del ozemlja Republike Slovenije, specialne in druge enote Slovenske vojske izvajajo nekonvencionalne vrste bojnega delovanja s poudarkom na gverilski taktiki. Enote se preoblikujejo v manjše skupine, katerih cilj je nenehno motenje, uničevanje, nevtraliziranje in zmanjšanje morale sovražnika. Bojno delovanje je samostojno, agresivno, prikrito, inovativno, neprekinjeno in sili sovražnika v vzdrževanje statične razporeditve, pri čemer se povečuje manevrski prostor Slovenske vojske. Enote se izogibajo frontalnemu bojevanju. Napadalnost in presenečenje sta temeljni načeli, po katerih enote izvajajo bojna delovanja na zasedenem ozemlju. (Furlan idr., 2006, str. 51-52) 


\section{NALOGE NATOVIH SPECIALNIH SIL}

\subsection{Osnovne naloge Natovih specialnih sil}

SVS STANAG 2523(1), Združena zavezniška doktrina specialnih operacij, opredeljuje osnovne naloge Natovih specialnih sil (v nadaljevanju naloge), in sicer:

- specialno izvidovanje (Special Reconnaissance - SR), to so aktivnosti zbiranja obveščevalnih podatkov, ki dopolnjujejo nacionalne ter zavezniške obveščevalne vire in sisteme s pridobivanjem posebnih, natančno določenih in časovno pomembnih informacij na operativni in strateški ravni. Ko v oteženih okoliščinah (velika aktivnost sovražnika, zahteven teren ipd.) izvidniško-obveščevalni organi $\mathrm{v}$ konvencionalnih silah ne morejo pravočasno zagotoviti natančnih in časovno pomembnih podatkov, se uporabijo specialne sile;

- neposredne akcije (Direct Action - DA) dopolnjujejo Natove zmožnosti z napadi na posebne, točno določene cilje strateškega ali operativnega pomena, po svojem obsegu in času delovanja so omejene. Glavni načini izvajanja teh akcij so: diverzije, naskoki, zasede, usmerjanje delovanja ognjene podpore z zemlje, iz zraka in z morja ter usmerjanje »pametnega orožja (npr. lasersko vodenih bomb);

- vojaška pomoč (Military Assistance - MA) obsega zelo različne ukrepe podpore prijateljskim ali zavezniškim silam. Specialne sile lahko v okviru vojaške pomoči sodelujejo pri usposabljanju, opremljanju, podpori in uporabi (delovanju) drugih sil.

Koncept razporeditve osnovnih nalog specialnih sil oziroma načelna razmerja med izvajanjem teh nalog med konfliktom so razvidna s slike 2, medtem ko slika 3 prikazuje načelni spekter izvajanja nalog v sklopu Natovega sistema kriznega upravljanja.

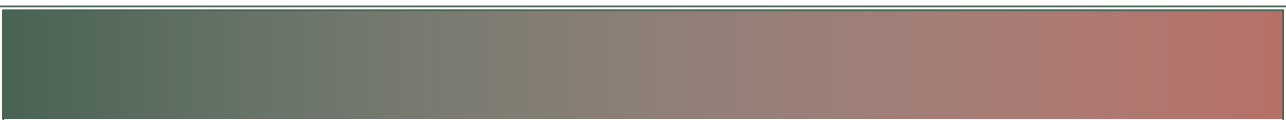

Uporaba vojske Operacije v v miru

\section{Bojne} operacije proti netradicionalnim

$$
\text { grožnjam }
$$

Bojne operacije večjega obsega

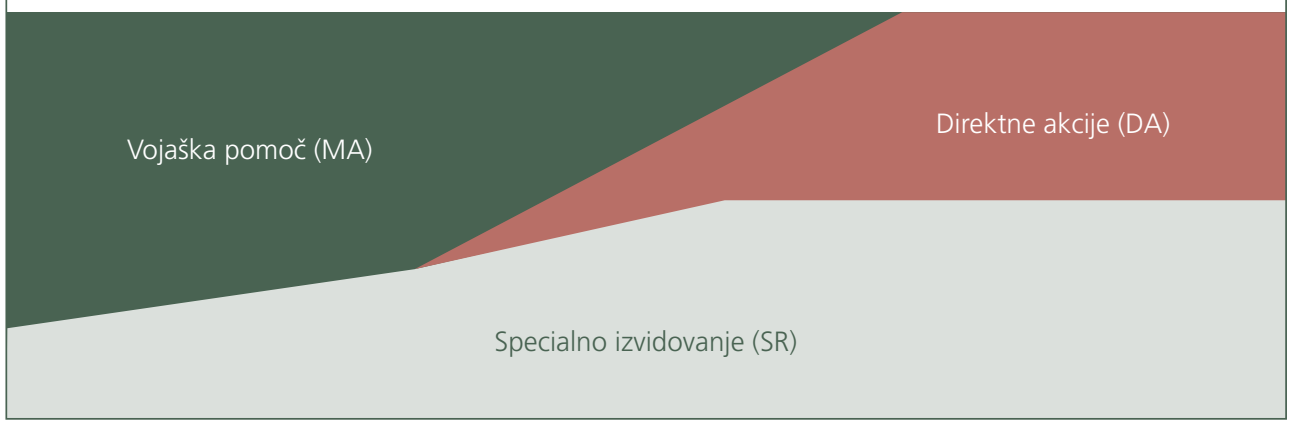


Slika 3: Natov sistem kriznega upravljanja in naloge SOF

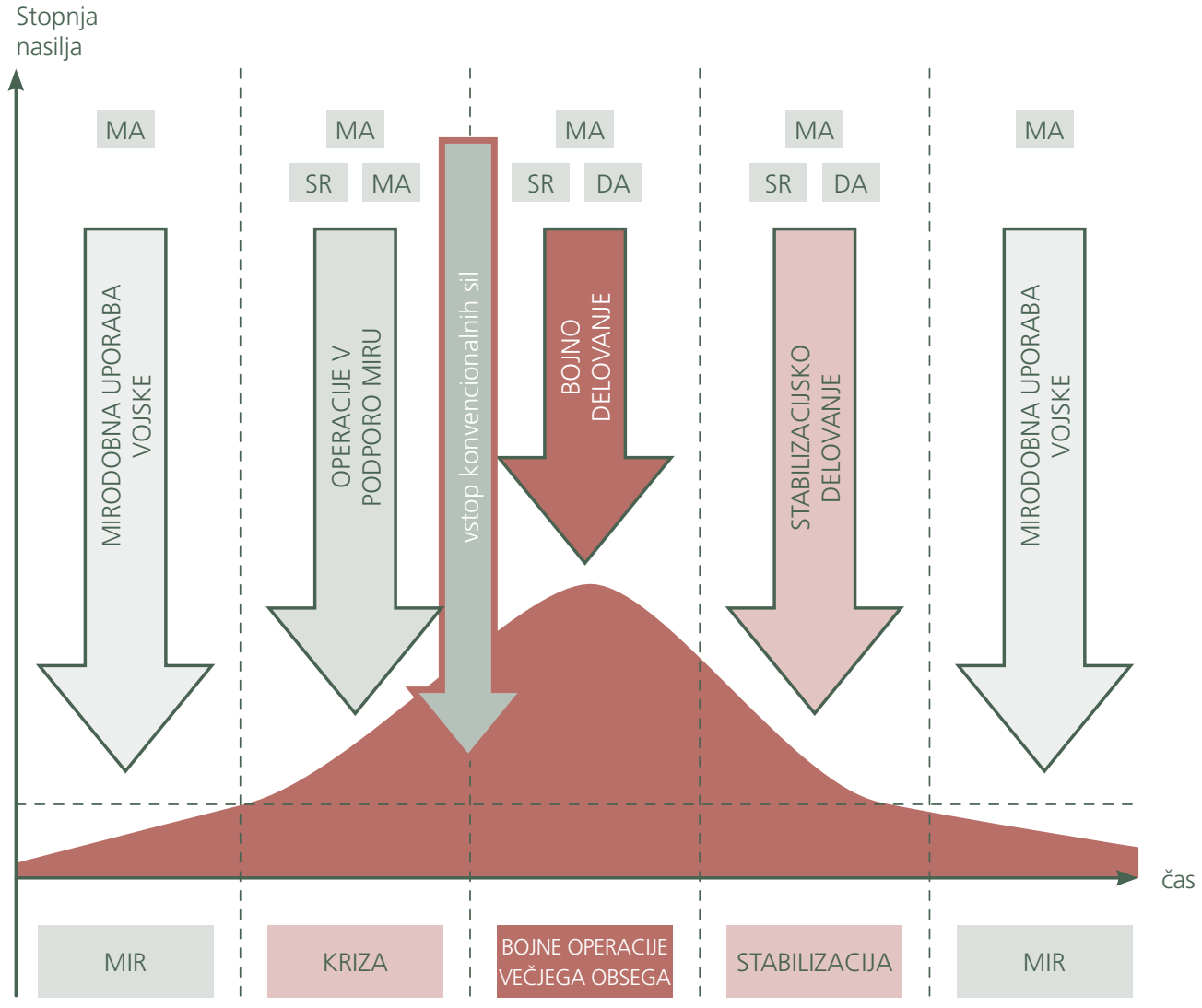

\subsection{Druge naloge Natovih specialnih sil}

Poleg osnovnih opredeljuje SVS STANAG 2523(1) še druge naloge, v katerih sodelujejo specialne sile zavezništva (niso pa izključni akter), in sicer:

- podpora v boju proti neregularnim aktivnostim sovražnika - vključuje protiteroristično ${ }^{4}$ in protiuporniško delovanje ${ }^{5} \mathrm{v}$ operacijah zavezništva;

- reševanje talcev - specialne sile lahko sodelujejo v teh delovanjih pod posebnimi pogoji.

Pomembno je poudariti, da ESD kljub svojim zmogljivostim nima zakonskih pooblastil za take aktivnosti na območju Republike Slovenije, zanje imata zakonska pooblastila Policija s Specialno enoto in Vojaška policija za objekte in območja SV (ZoBR).

4 Protiteroristično delovanje kot eno izmed nalog specialnih sil opredeljujeta Vojaška doktrina (2006: 50) in Direktiva za organiziranje in delovanje specialnih sil SV (2008: 4)

5 Protiuporniško delovanje kot eno izmed oblik specialnega delovanja je v Direktivi za organiziranje in delovanje specialnih sil SV (2008: 4) opredeljeno kot »/.../ podpora protiterorizmu in protiuporništvu (Support to

Counterterrorism and Counterinsurgency) «. 
Pri dokončni opredelitvi nalog specialnih sil SV bo zato treba še bolj upoštevati opredelitve v slovenskih normativnih dokumentih ter v MC 437/1 in AJP 3.5. Posebej to velja za dodatne naloge, v katerih lahko sodelujejo specialne sile SV. Sodelovanje v njih se določa na podlagi zakonskih pooblastil.

\section{TAKTIČNA SKUPINA ZA SPECIALNO DELOVANJE}

Vsi koncepti in standardi, ki so uveljavljeni v Slovenski vojski in Natu, se na koncu odrazijo v zmogljivostih. Te zmogljivosti so za posamezne države opredeljene v ciljih sil. Cilji sil SV opredeljujejo, da ESD Natu zagotavlja taktične skupine za specialno delovanje ${ }^{6}$ (TSSD). ESD je organizirana tako, da lahko zagotovi več taktičnih skupin za specialno delovanje. Nato opredeljuje njihove zmogljivosti in razlike med njimi. Taktična skupina za specialno delovanje iz ESD ima tako element poveljevanja in kontrole, bojni element ter elemente bojne podpore in zagotovitve delovanj. S teh izhodišč so zmogljivosti bojne skupine:

- načrtovanje in izvajanje specialnega delovanja v sovražnih okoljih, samostojno ali kot sestavni del večje formacije, $\mathrm{z}$ drugimi vojaškimi in varnostnimi strukturami lastnih ali zavezniških sil ter sil države gostiteljice;

- izvajanje celotnega spektra specialnega delovanja v odvisnosti od posebnih odobritev;

- premeščanje in razmeščanje $\mathrm{v}$ načrtovanih časovnih okvirih, z vsemi razredi oskrbe;

- infiltracija in eksfiltracija po kopnem ter po zraku ali vodi;

- izvajanje specialnega delovanja na odročnih območjih in v sovražnih okoljih za daljše obdobje in z minimalno zunanjo podporo;

- izvajanje nalog v podskupinah;

- izvidovanje ter nadzor ciljev podnevi in ponoči, izvajanje nadzora peš in z vozili;

- izvajanje omejenih napadov z daljave z ostrostrelnim orožjem in prenosnimi eksplozivnimi napravami (man-pack explosive devices);

- manevrsko delovanje $\mathrm{z}$ uporabo taktičnih prevoznih sredstev in skupinskega orožja za podporo;

- navajanje ter zaključno usmerjanje letalskih napadov ter neposredne zračne podpore;

- navajanje ter zaključno usmerjanje precizno vodenega streliva na cilj;

- razvijanje, organiziranje, usposabljanje in svetovanje oziroma usmerjanje vojaških ali/in paravojaških sil države gostiteljice $-\mathrm{z}$ dodanimi prevajalskimi zmogljivostmi.

Zaradi zahtevnosti nalog in razmer, v kakršnih delujejo pripadniki enot za specialno delovanje, sta oprema in oborožitev drugačni kot v drugih enotah. Zaradi različnih načinov in okoliščin delovanja imajo pripadniki specialnih enot več kompletov namenske opreme in oborožitve.

${ }^{6}$ Special Operations Task Group - SOTG. 


\section{KONCEPT „NA UČINKIH TEMELEČE OPERACIJE«}

Koncept »na učinkih temelječe operacije« (UTO) se je na taktični ravni pojavil v zračnih silah ZDA, in sicer v obdobju prve zalivske vojne. Nanaša se na načrtovanje in vodenje bojnega delovanja $z$ združitvijo vojaških in nevojaških metod za doseganje učinka. Razvit je bil za izkoriščanje velikega napredka vojaške tehnologije in razvoja taktike, pri čemer je poveljnikov namen lahko dosežen z minimalno stransko škodo ter minimalnim tveganjem za lastne sile (Batschelet, 2002).

Koncept so pozneje preizkušali tudi na strateški in operativni ravni, vendar so ga zaradi različnih interpretacij ter zaradi mnenja, da daje poveljnikom lažen občutek predvidljivosti bojišča (Mattis 2008), uradno umaknili iz splošne uporabe in ga nadomestili s konceptom »Comprehensive Approach«. Kot govorijo najpomembnejši kritiki, je koncept $\mathrm{v}$ primerjavi s tradicionalno operatiko uporaben predvsem $\mathrm{z}$ vidika izbire in delovanja na cilje, in sicer na taktični ravni (Vego, 2006; Mattis, 2008; Riper, 2009; glej tudi Smolej, 2011). Tako je, čeprav umaknjen iz uporabe na višjih ravneh poveljevanja, še vedno učinkovito orodje Natovih specialnih sil za določanje ciljev na taktični ravni.

Specialne sile imajo na taktični ravni v bistvu veliko več obveščevalnih informacij o sovražniku kot konvencionalne. To jim omogoča veliko boljši vpogled v stanje na bojišču, saj se konvencionalne sile pogosto na začetku bojnega delovanja znajdejo z omejenim situacijskim zavedanjem. Prav na podlagi večje količine obveščevalnih informacij imajo specialne sile več manevrskega prostora v procesu določanja ciljev, v katerem z uporabo koncepta UTO usmerjajo svoje delovanje v smislu doseganja posebnih učinkov.

Na asimetričnem bojišču to v praksi navadno pomeni, da se poveljniki enot specialnih sil osredotočajo predvsem na cilje, za katere imajo kakovostne in zadostne obveščevalne informacije ${ }^{7}$. Te cilje lahko tudi sami prikrito spremljajo in nadzorujejo (Small footprint) ter $\mathrm{v}$ izbranem trenutku $\mathrm{z}$ veliko natančnostjo nevtralizirajo. $\mathrm{Na}$ drugi strani pa poveljniki nižjih taktičnih enot konvencionalnih sil svoje sile uporabljajo predvsem v smislu prikaza moči (Show the Force), s katerim odvračajo sovražnika od uresničevanja njegovih namer (Big footprint). Če med izvajanjem svojih nalog naletijo na sovražnika ${ }^{8}$, poskušajo z njim obdržati stik in ga $\mathrm{z}$ okrepitvami uničiti (slika 2).

\footnotetext{
Menimo sicer, da je lahko tak način pri tako imenovanih anti head operacijah, če je izveden površno, sporen in kontraproduktiven, saj lahko še bolj podžge uporniško delovanje. To se vidi tudi na primeru prenosa strategije generala Petreusa iz Iraka v Afganistan, kjer ni dosegla želenih učinkov (glej tudi Svete, Guštin, Črnčec, 2011).

8 Fizični stik ali obveščevalne informacije.
} 


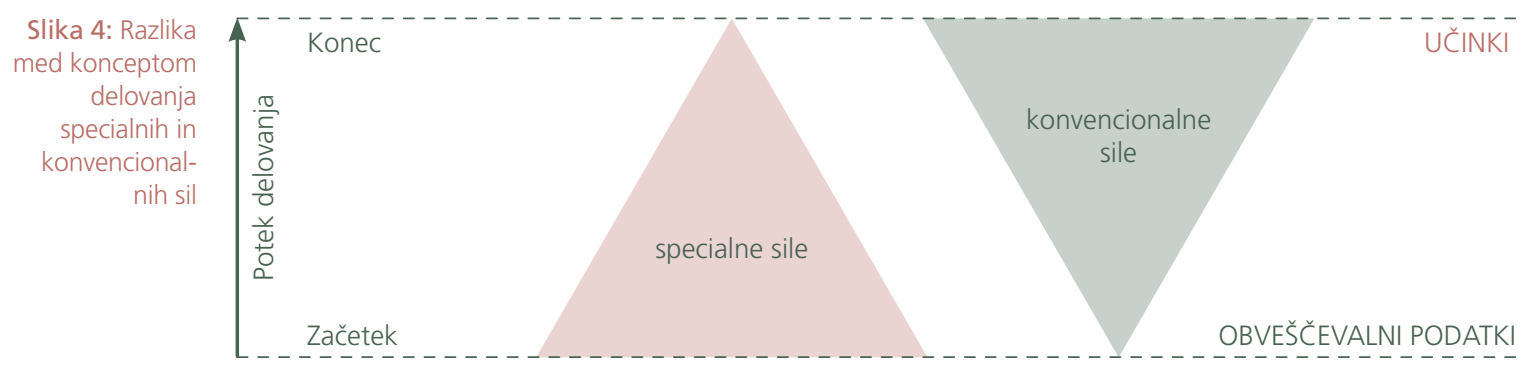

Ko govorimo o učinkih, je treba omeniti predvsem dva vidika, prvi je učinek v taktičnem smislu in je načeloma vezan predvsem na škodo, ki je povzročena sovražniku. Drugi je vezan na operativno raven, in sicer na širše učinke v nekem geografskem in socialnem okolju.

Tako Smith (2006) ugotavlja, da bodo konflikti in spopadi v prihodnje potekali med civilnim prebivalstvom. Glavni akterji konflikta ne bodo države in njihove oborožene sile, temveč različne druge organizirane oblike 9 . Med njimi bo delovanje oboroženih sil po konvencionalnih vojaških načelih povzročilo nepotrebne žrtve in dodaten odpor.

Vojaška operacija je lahko uspešna v taktičnem smislu, vendar je njeno delovanje lahko kontraproduktivno na operativni ravni. To pa pomeni izgubo zaupanja, točke osredotočenja ${ }^{10}$ pa niso dosežene.

To se pogosto dogaja v protiuporniškem bojevanju $\left(\mathrm{COIN}^{11}\right)$, v katerem je sovražnikovo delovanje pogojeno predvsem s podporo lokalnega prebivalstva (Celeski, 2005). Tako lahko sicer uspešne vojaške operacije ${ }^{12}$ na taktični ravni zaradi stranskih učinkov med civilnim prebivalstvom in na civilni infrastrukturi ali zaradi neodobravanja lokalne skupnosti premaknejo težišče naklonjenosti k sovražniku, kar pa na operativni ravni pomeni veliko več truda in časa za vzpostavitev varnega okolja.

\footnotetext{
9 Pri tem se lahko srečamo z mrežno organiziranostjo teroristov/sovražnikov, ki bi jo lahko označili tudi kot organizacijsko asimetrijo. Organizacijska simetrija je bila v zgodovini vojskovanja vedno zelo pomembna. Inovacije so akterjem namreč omogočale veliko prednost, tudi če niso imele tehnološke ali druge prednosti. Tudi Svete (2007, str. 13) trdi, »/.../ da se bodo državne institucije soočile z nedržavnim nasprotnikom, ki bo organiziran v mreže, ne pa hierarhično, kot je organizirana večina državnih institucij na področju nacionalne varnostik.

${ }^{10}$ Teroristi/uporniki delujejo po ljudeh, ki so naša točka osredotočenja (TOS), pri tem ima njihovo taktično delovanje strateški učinek. Točke osredotočenja (angl. Centres of Gravity-COG) so definirane kot značilnosti, zmogljivosti ali prizorišča, iz katerih država, zavezništvo, vojaške sile ali druge skupine črpajo svobodo svojega delovanja, fizično moč ali voljo za boj. Te točke obstajajo na taktični, operativni in strateški ravni in pomenijo središče moči ali delovanja, od katerega je vse odvisno, oziroma so točka, v katero je treba usmeriti vso energijo za doseganje cilja. Iz te točke izhajajo sposobnost, moč in volja nasprotnikovih sil. Uničenje ali onesposobitev te točke pomeni doseganje odločilne prednosti in zmago.

${ }^{1 I}$ COIN-Counter-insurgency.

${ }_{12}$ Uspešne v smislu linearnega bojišča, pri čemer je bil cilj predvsem škoditi sovražniku.
} 
Zato je vodilo bojnega delovanja specialnih sil »razmišljaj operativno, deluj taktično« (Think operational, act tactical). Pri tem je pomembno poudariti, da naj bi specialne sile v protiuporniškem bojevanju v primerjavi s konvencionalnimi, ki izvajajo predvsem kinetične operacije ${ }^{13}$ (Smith, 2008), izvajale predvsem nekinetične operacije. To pomeni, da lahko za doseganje svojih ciljev izvajajo naloge psihološkega delovanja, civilno-vojaškega sodelovanja, vojaške pomoči ipd. Tako so specialne sile oboroženih sil ZDA leta 2009 ponovno odkrile koncept Village Stability Operations (VSO), ki je bil v uporabi že med vietnamsko vojno. Glavna značilnost koncepta je, da se manjše skupine specialnih sil nastanijo v ključnih vaseh ali naseljih in v smislu dobrega soseda pomagajo lokalnim skupnostim pri reševanju njihovih težav. Ta pomoč lahko variira od zagotovitve varnega okolja do pomoči pri uvedbi lokalne samouprave ${ }^{14}$ in ključne infrastrukture, ki je pomembna za normalno delovanje nekega socialnega okolja. V primeru Afganistana pa je ena izmed ključnih nalog teh specialnih sil zagotovitev povezave lokalne uprave z osrednjo vlado (Government of Islamic Republic of Afghanistan - GIRoA). Glejte že omenjeno knjigo, v kateri je analizirano tudi protiuporniško delovanje okupatorja na slovenskem ozemlju med drugo svetovno vojno.

Koncept UTO je za ESD pomemben, ker glede na svoja izhodišča in druge enote Slovenske vojske narekuje vsebinsko prilagojen proces usposabljanja, ki pa mora biti povezan tako s posamezniki kot tudi z enoto. Za delovanje skladno s konceptom UTO morajo imeti enote specialnih sil veliko večje generične zmožnosti za pridobivanje obveščevalnih podatkov in močnejše analitične zmožnosti za njihovo obdelavo. Poleg tega morajo biti bolj prilagodljive, saj imajo lahko številčno manjše enote specialnih sil veliko večji spekter zmogljivosti, celo v primerjavi večjimi konvencionalnimi enotami. To bi med drugim moralo biti tudi posledica izbirnih postopkov za popolnjevanje teh enot, saj zagotavljajo kadrovsko popolnjenost s sposobnejšim kadrom (glej Spulak, 2007, str. 20).

\section{POTRDITEV TEZ IN TAKTIČNA VAJA RIS 2011}

Po doktrinarnih in normativnih opredelitvah specialnih sil, njihovi postavitvi in opremljanju, mora vsaka vojska svoje specialne sile tudi preveriti in preizkusiti.

ESD že od leta 2004 deluje v mednarodnih operacijah in na misijah, v katerih SV v praksi preizkuša svoje doktrinarne rešitve. Tako je ESD kot prva v SV opravljala naloge v Afganistanu, Čadu, Libanonu, Iraku itn., znotraj operacij Nata, Evropske unije in OZN.

\footnotetext{
13 Termin kinetične operacije (Kinetic Operations) se nanaša na bojno delovanje, pri katerem se uporablja fizična sila.

${ }^{14}$ Predvsem v smislu lokalnih varnostnih služb.
} 
Pri tem je treba poudariti, da naloge ESD v Afganistanu spadajo predvsem med naloge vojaške pomoči (SVNKON 7 Isafa - OMLT ${ }^{15}$, NTM- ${ }^{16}$ ), delno med izvidniško delovanje (Afganistan SVNKON 1 in 2 Isafa, SVNKON 1 Unifila v Libanonu, SVNKON 1 v Altehei in SVNKON 1 v Čadu). V Afganistanu je ESD opravljala tudi bojno iskanje in reševanje (Afganistan SVNKON 1 in 2 Isafa) in informacijske operacije (INFOOPS, SVNKON 11 Isafa). ESD do zdaj v klasičnih neposrednih akcijah predvsem zaradi vrste nalog, ki jih je sprejela SV, in nacionalnih omejitev ni sodelovala. Kljub dejstvu, da ESD še ni sodelovala v neposrednih akcijah, je pridobila dragocene izkušnje in se dokazala v najzahtevnejših okoljih. Sodobne specialne sile se namreč vse bolj posvečajo nalogam vojaške pomoči in specialnega izvidovanja, kamor spada tudi pridobivanje podatkov s človeškimi viri.

Kot navaja Paternus (2010, str. 64) je operacija Isafa test pripravljenosti in usposobljenosti, ne samo za ESD, temveč tudi za Slovensko vojsko kot celoto, ki je v vojaški operaciji prvič delovala zunaj območja jugovzhodne Evrope. Poleg tega je delovanje v več kot $6000 \mathrm{~km}$ oddaljenem puščavskem okolju strokovni izziv in velik logistični dogodek, tako za pripadnike ESD kot tudi za vso Slovensko vojsko. Glede na analizo nalog Natovih enot za specialno delovanje v vojaški operaciji Trajna svoboda (Enduring Freedom) je Paternus (2010) ugotovil primerljivost nalog ESD v Isafu, ki so obsegale:

- globinsko izvidovanje in obveščevalne operacije,

- operacije bojnega iskanja in reševanja,

- iskanje in uničenje skrivališč orožja in streliva,

- urjenje pripadnikov zavezniških sil.

Pridobljene izkušnje iz opravljenih nalog SVNKON 1 in 2 Isafa kažejo na sposobnost ESD za specialno delovanje skladno z Natovimi normativi (AJP 3.5). Glede na zahtevnost nalog in uspešnost pri izvedbi, brez izrednih dogodkov oziroma poškodb, Paternus (2010) ugotavlja, da so pripadniki ESD ustrezno opremljeni, usposobljeni in pripravljeni za specialno delovanje. Njegovo ugotovitev potrjuje tudi delovanje SVNKON 14 in 15 Isafa - OMLT, kamor so vključeni tudi pripadniki ESD.

V operaciji NTM-I so pripadniki ESD z vojaško pomočjo usposabljali pripadnike iraških varnostnih sil. Svoje naloge so opravljali v iraški vojaški akademiji za častnike Al Rustamijah. Pri usposabljanju iraških častnikov so delovali podobno kot pripadniki SVNKON 7 Isafa - OMLT, pri čemer je zagotavljanje varnosti posameznika predstavljalo še večji izziv. Kljub kulturnim razlikam med pripadniki afganistanskih in iraških varnostnih sil so pripadniki ESD dokazali, da so dovolj kulturno osveščeni in sposobni delovati v tujem kulturnem in socialnem okolju, kar je ena temeljnih značilnosti specialnih sil.

\footnotetext{
${ }_{15}$ Kljub vsem zaslugam SVNKON 14 Isafa, ki je usposabljanje bataljona afganistanske vojske začel leta 2010 je treba poudariti, da je ESD usposabljala afganistansko vojsko že leta 2006. Prav tako so pripadniki ESD usposabljali pripadnike iraške vojske v misiji NTM-I v Iraku leta 2006.

${ }^{16}$ NTM - I: NATO Training Mission - Iraq.
} 
Podobne izkušnje pri delovanju na oddaljenem in zahtevnem puščavskem območju je ESD pridobila v operacijah CAR/Čad in Unifil. Naloge, ki so jih pripadniki opravljali za enote brigadne ravni, spadajo v specialno izvidovanje. Delovali so v lahkih oklepnih vozilih, stopnja samozadostnosti oskrbe je bila velika, kar je bistvena razlika v primerjavi z operacijo Isafa. Velik izziv so bila predvsem terenska vozila, ki morajo imeti v puščavskem okolju večji akcijski radij, medtem ko je zaščita proti improviziranim eksplozivnim napravam (IEN), vsaj v primeru operacije v Čadu, manj pomembna. Obe operaciji, čeprav pod okriljem EU in OZN, sta z vidika opravljenih nalog potrdili koncepte usposabljanja enote. Tudi v teh operacijah so se doktrinarne in konceptualne rešitve, ki izhajajo iz SVS STANAG 2523(1), pokazale kot ustrezne.

Ves obseg nalog (neposredne akcije, specialno izvidovanje in vojaška pomoč), za katerega se ESD usposablja, se preizkusi na taktičnih vajah.

Tako se običajno pred pravo bojno uporabo izvedejo usposabljanja in vaje ter tako preizkusijo teoretični koncepti in rešitve. Tudi ESD je svoje konceptualne rešitve ter zmogljivosti za izvedbo bistvenih nalog in poslanstva preverila na taktični vaji RIS 2011.

Republika Slovenija se je obvezala, da skladno z načrti razvoja SV v sklopu ciljev sil do leta 2012 razvije in pripravi taktično skupino za specialno delovanje (TSSD), katere nosilec je Enota za specialno delovanje. Za doseganje tega cilja je enota izvedla taktično vajo RIS 2011, katere glavni namen je bil preveriti TSSD pri specialnem delovanju v podporo protiuporništvu (COIN), in sicer v razmerah asimetričnega bojišča, v kakršnem trenutno delujejo enote SV v operaciji International Security Assistance Force (ISAF) v Afganistanu. Hkrati je ESD želela preveriti zmožnost TSSD za izvajanje združenega bojevanja rodov, saj to zagotavlja sinergične učinke $(1+1=3)$, ki specialnim silam omogočajo relativno premoč ${ }^{17} \mathrm{v}$ prostoru in času nad številčno močnejšim sovražnikom. Na vaji so sodelovale enote sil SV (slika 5):

- ESD z elementi:

- poveljstvo z izvajanjem nalog poveljevanja in kontrole (PINK),

- bojne skupine, ki so izvajale kinetične operacije (DA) in vojaško pomoč (MA) v povezavi s konvencionalnimi silami države gostiteljice (HN) ter pridobivale in potrjevale obveščevalne informacije - specialno izvidništvo (SR),

- logistična skupina (LOGSK) za bojno zagotovitev delovanja;

- Letalska šola (LETŠ) z zrakoplovi PC-9M Hudournik za ognjeno podporo iz zraka;

- 15. helikopterski bataljon (HEB) za zagotovitev zračne premičnosti;

- 5. obveščevalno-izvidniški bataljon (OIB) s skupino brezpilotnih letal (BPL) za zagotovitev obveščevalnih podatkov - slikovnega gradiva $\left(\mathrm{IMINT}^{18}\right)$ ter za nadzor ciljev;

- 460. artilerijski bataljon (AB) za topniško podporo;

- 20. motorizirani bataljon (MOTB) z izvidniškim vodom (IZVOD), ki je opravljal naloge sil države gostiteljice.

\footnotetext{
${ }^{17}$ Relative Superiority (McRaven, 1995).
}

${ }^{18}$ IMINT-Image Intelligence. 
Slika 5: Organizacija sil vadbenih elementov za vajo RIS 2011

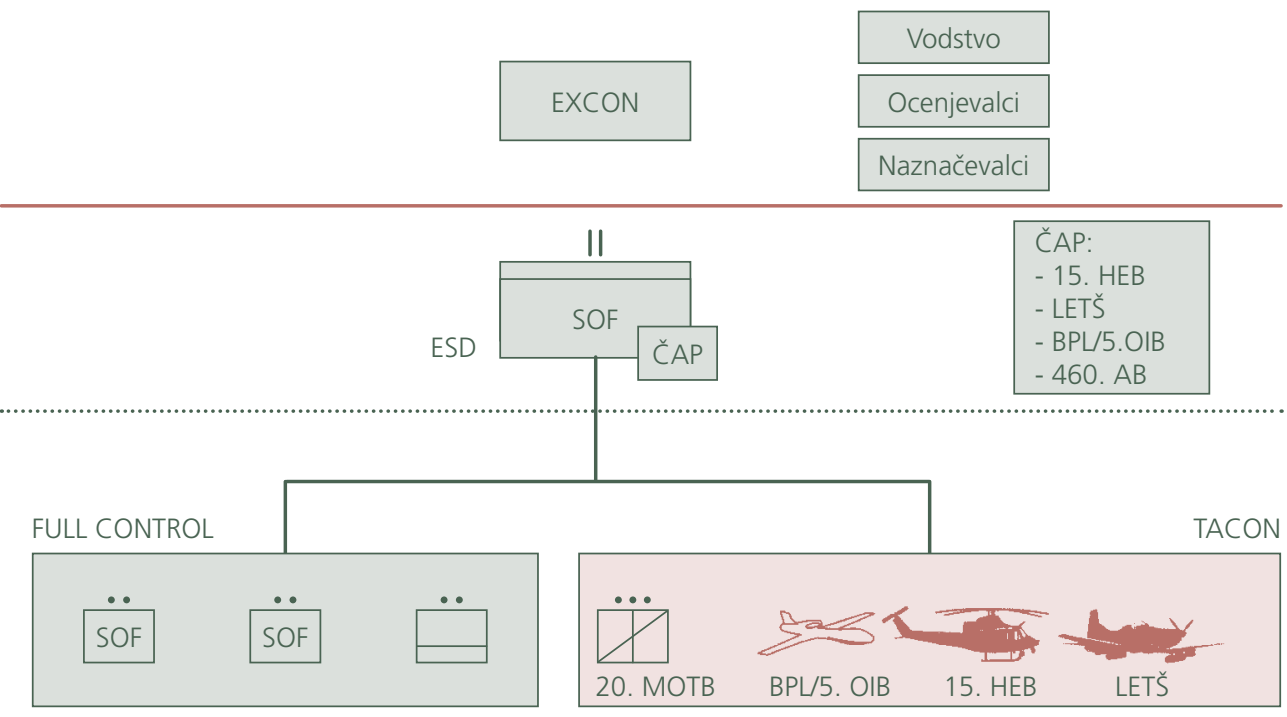

ESD je za stvarno preverjanje odzivnosti in delovanja enote načrtovala izvedbo vaje po načelu klasičnega delovanja v mednarodnih operacijah in na misijah (MOM), in sicer na vadbeni situaciji Afganistana.

Glede na vadbeno situacijo je dobila nalogo poiskati in v sodelovanju s silami države gostiteljice zajeti osebo oziroma cilj visoke vrednosti. Z izvedbo naloge naj bi pridobila nove obveščevalne podatke, s katerimi bi onemogočila delovanje sovražnikove mreže, hkrati pa bi prikazala zmožnost in zanesljivost osrednje afganistanske vlade - GIRoA ${ }^{19}$, da zagotavlja suverenost v določeni provinci.

V prvem delu vaje je enota skupaj s skupino BPL vadila pridobivanje obveščevalnih podatkov na območjih posebnega interesa $\left(\mathrm{NAI}^{20}\right)$. Po obveščevalni analizi slikovnega gradiva (IMINT) je na podlagi teh informacij opravila še proces premišljenega odločanja po modelu Military Decision Making Process in skladno z odobreno varianto delovanja izdala naloge podrejenim enotam. Hkrati je na dislocirani lokaciji bojna skupina izvedla usposabljanje voda države gostiteljice in tako ustvarila razmere za skupno združeno (Combined Joint) bojno delovanje.

V nadaljevanju vaje se je bojna skupina, razdeljena na dve podskupini, ob zračni podpori premaknila na dve ločeni ciljni interesni območji $\left(\mathrm{TAI}^{21}\right)$ in zagotovila njuno opazovanje ter nadzor. V nadaljevanju je ena podskupina opravila pozitivno identifikacijo iskane osebe, medtem ko je druga locirala in identificirala osebo z združene

\footnotetext{
19 GIRoA - Government of Islamic Republic of Afghanistan.

${ }^{20}$ NAI - Named Area of Interest.

21 TAI - Target Area of Interest.
} 
liste iskanih oseb (JPETL ${ }^{22}$ ). Po predaji slikovnega gradiva poveljstvu ESD je to potrdilo pozitivno identifikacijo ciljev in se na podlagi štabne analize odločilo, da iskano osebo zajame z združeno enoto lastnih sil in sil države gostiteljice, medtem ko drugi cilj visoke vrednosti zaradi njegovega profila in zaradi omejenih lastnih bojnih zmogljivosti uniči z letalskim ognjem.

Na prvem ciljnem interesnem območju je podskupina s pomočjo para letal PC-9M Hudournik z letalskim ognjem uničila cilj. Uničenje cilja brez stranske škode je pozneje potrdilo tudi slikovno gradivo, ki ga je za oceno bojne škode posnela skupina BPL. Istočasno je na drugi, oddaljeni geografski lokaciji združena enota opravila premik na drugo ciljno interesno območje in zajela iskano osebo. Po zajetju je na kraju dogodka zbrala in zavarovala obremenilne dokaze ( $\left.\mathrm{SSE}^{23}\right)$, ki jih je pozneje skupaj z zajeto osebo predala poveljstvu ESD. Poveljstvo je izvedlo vse nadaljnje predvidene postopke.

Sklep Tako v mednarodnih operacijah in na misijah kot na taktični vaji RIS 2011 je ESD pokazala, da je vrhunsko usposobljena enota, ki tvori ost enot za bojno delovanje Slovenske vojske. Enota je doslej v praksi in na vaji preverila in potrdila zmogljivost specialnega delovanja ter združenega bojevanja rodov v podporo nalogam protiuporništva (COIN), in sicer v razmerah asimetričnega bojišča, na kakršnem trenutno delujejo enote SV v operaciji Isafa. S potrditvijo svojih zmogljivosti v praksi je ESD pokazala, da so predlagani teoretični koncepti in rešitve, na katerih temelji, pravilni in uresničljivi. S tem je ponovno potrdila svojo zavezanost k odličnosti in preseganju standardov. Ponovno so se potrdili reki, da je kakovost pomembnejša od količine, da je človek s svojim znanjem in izkušnjami pomembnejši od opreme, pa tudi, da pripadnikov specialnih sil ni mogoče usposobiti na hitro, tudi če je nuja.

Za dokončno umestitev med specialne sile in za specialno delovanje v Natu, $\mathrm{v}$ resnični operaciji, je treba določiti tudi vodilno državo (Leading Nation), kar pa ni $\mathrm{v}$ pristojnosti ESD.

Sistemski in celovit pristop k oblikovanju ESD zagotavlja zmogljivost specialnega delovanja Slovenske vojske in posebnih nacionalnovarnostnih ciljev Republike Slovenije. Usposabljanje in opremljanje enot za specialno delovanje je dolgotrajen proces, ki mu morata država in vojska nameniti dovolj pozornosti (tudi kadrovskih in materialnih virov).

Visoka usposobljenost, sposobnost prikritega delovanja, zmožnost velike natančnosti zaradi zmanjševanja stranskih učinkov in velika prilagodljivost glede na različne vire ogrožanja so samo nekatere značilnosti, ki poudarjajo vlogo in pomen ESD znotraj oboroženih sil. Te značilnosti omogočajo njeno uporabo za izpolnjevanje obveznosti Republike Slovenije do sistema Natove kolektivne obrambe ter

22 JPETL - Joint Priority Enemy Target List.

${ }_{23}$ SSE - Sensitive Site Exploitation. 
zagotavljanje mednarodne varnosti v mednarodnih operacijah in na misijah znotraj OZN, ko drugih enot in zmogljivosti Slovenske vojske ni mogoče uporabiti. Hkrati pa Republika Slovenija pridobi tudi zmogljivosti za obrambo države in delovanje v posebnih kriznih razmerah ${ }^{24}$ protiterorističnega delovanja v Republiki Sloveniji.

\section{Literatura}

1. AJP-3.5. Združena zavezniška doktrina specialnih operacij (izvirnik januar 2009, slovenski SVS STANAG 2523(1), julij 2009). Ljubljana: MO RS.

2. Batschelet, A. W., 2002. Effects-based operations: A new Operational Model? Strategy Research Project, U.S. Army War College. http://www.iwar.org.uk/military/resources/ effect-based-ops/ebo.pdf, 5. 5. 2011.

3. Beršnak, K., 2010. Preoblikovanje vloge in načinov delovanja enot za specialno delovanje zveze Nato v povezavi z evolucijo tipologije vojskovanja. Diplomsko delo, Maribor: Fakulteta za varnostne vede.

4. Celeski, J, D., 2005. Operationalizing COIN. Joint Special Operations University (JSOU) Report 05-2.

5. Furlan, B., in drugi, 2006. Vojaška doktrina. Ljubljana: Defensor.

6. Mattis, J. N., 2008. USJFCOM Commander's Guidance for Effects-based Operations. Parameters, Vol. XXXVIII, pomlad 2008. str. 18-25. http://www.carlisle.army.mil/usawc/ Parameters/Articles/08autumn/mattis.pdf, 9. 6. 2010.

7. Newton, R., 2010. Introduction to Special Operations. What makes SOF special. PPpredstavitev, Chievres: NATO SOF.

8. Paternus, U., 2010. Preoblikovanje vojaških specialnih enot držav zveze NATO. Magistrsko delo, Ljubljana: Fakulteta za družbene vede.

9. Prezelj, I.,2007. Nujnost medresorskega sodelovanja in koordiniranja v boju proti terorizmu: nekateri primeri iz Republike Slovenije. V: Bilten Slovenske vojske 2007-9/št. 2. Ljubljana: Generalštab Slovenske vojske, str. 65-80.

10. Resolucija o splošnem dolgoročnem programu razvoja in opremljanja Slovenske vojske do leta 2025 (ReSDPRO SV 2025), 2010. Uradni list R, št. 99/2010 z dne 7. 12. 2010.

11. Riper, K. P., 2009. EBO There Was No Baby in the Bathwater. Joint Force Quaterly Issue 52, str. $82-85$.

12. Rode, A., 2007. Vojaška obveščevalna dejavnost. Magistrsko delo. Celje: Fakulteta za logistiko.

13. Smith, H., 2008. Kinetic and Nonkinetic Versus Lethal and Nonlethal Operations.

14. http://www.captainsjournal.com/2008/06/30/kinetic-and-nonkinetic-versus-lethal-andnonlethal-operations/

15. Smith, R., 2006. The Utility of Force. The Art of War in the Modern World. London: Penguin Books.

16. Smolej, S., 2011. Kritična analiza na učinku temelječih operacij. Magistrsko delo, Ljubljana: Fakulteta za družbene vede.

17. Srednjeročni obrambni program 2007-2012 (SOPR), št. 803-2/2006-58 z dne 27. 11. 2006.

18. Spulak, R., 2007. A Theory of Special Operations. Joint Special Operations University (JSOU) Report 07-7. http://jsoupublic.socom.mil/publications/jsou/JSOU077spulakATheoryofSpecialOps_final.pdf, 4. 6. 2010.

19. Svete, U., 2007. Asimetrični konflikti in mirovne operacije. Poljče, Center za obrambno usposabljanje. 19. 11. 2007.

\footnotetext{
${ }^{24}$ Uporaba vojaških zmožnosti bojnega delovanja ob razglasitvi izrednih razmer.
} 
20. Svete, U., in drugi, 2011. Asimetrija in nacionalna varnost: od zgodovinskih izkušenj do sodobnih izzivov. Knjižnica Jurija Vege. Ljubljana: Defensor.

21. Vego, N. M., 2006. Effects-Based Operations: A Critique. Joint Force Quaterly Issue 41, str. $51-75$. 